\title{
Cost Analysis of RCC, Steel and Composite Multi-Storied Car Parking Subjected to High Wind Exposure in Bangladesh
}

\author{
Mir Abdul Kuddus ${ }^{a^{*}}$, Partha Pritom Dey ${ }^{b}$ \\ ${ }^{a}$ Assistant Professor, Department of Civil Engineering, Khulna University of Engineering \& Technology, Khulna-9203, Bangladesh. \\ ${ }^{b}$ Undergraduate Student, Department of Civil Engineering, Khulna University of Engineering \& Technology, Khulna-9203, Bangladesh . \\ Received 19 January 2017; Accepted 27 February 2017
}

\begin{abstract}
Steel-concrete composite constructions in Bangladesh are nowadays very popular owing to their advantages over conventional concrete and steel constructions. Concrete structures are massive and allot more seismic weight and less deflection whereas steel structures instruct more deflections and ductility to the structure, which is beneficial in resisting earthquake and wind forces. Composite construction combines the better properties of both steel and concrete along with lesser cost, speedy construction, fire protection etc. The objective of this study was to analysis and design ground floor plus 19 storied R.C.C, Steel and Composite (steel-concrete) multi-storied parking structure's frame of same plan using ETABS 2013 software and compare their structural parameters with estimated cost for required material. All frames are designed for same gravity and dynamic loadings. The RCC deck-slab is used in steel and composite frame. Beam and column sections are made of RCC, steel or steel-concrete composite sections. The composite construction option provided about $25 \%$ and $18 \%$ less cost when compared to RCC and steel structure, respectively. Comparative study concludes that the composite frames are best suited among all the three types of constructions in terms of material cost and benefit added with better structural behaviour.
\end{abstract}

Keywords: RCC Structure; Steel-RCC Composte; Cost analysis; Base Reaction; Story Displacement.

\section{Introduction}

In this study, 3 separate ground plus 19 storied buildings of R.C.C., Steel and Steel-Concrete composite frame are designed by ETABS software and the design parameters are considered for relative comparison. The literature relating to R.C.C., Steel and Steel-Concrete composite structure for designing concept are reviewed. Evaluation of load patterns and lateral forces according to UBC 94 code were assigned and then the static and dynamic analysis was performed by using response spectrum analysis in ETABS to design the building. Then the comparative dynamic behaviour is reviewed and estimation of the cost of superstructures frame is also calculated to find out the comparative differences. The building is considered to be constructed in Mongla Port, second largest international sea port in Bangladesh. Moreover, the building is designed to use as a multi-storied car parking for imported car from different countries of the world. The port is located $48 \mathrm{~km}$ south of Khulna city. The Port is surrounded as well as well protected by the Sundarban mangrove forest. The port is situated at the confluence of the Pashur River and the Mongla River. It lies about 62 miles $(100 \mathrm{~km})$ north of the Bay of Bengal. According to Bangladesh National Building Code (BNBC 2010), the basic wind speed is taken for Mongla Port Area is $279 \mathrm{~km} / \mathrm{hr}$ [1]. In Bangladesh most of the building structures fall under the category of low rise buildings. So, for these structures reinforced concrete members are used widely because the construction becomes quite convenient and economical in nature. But since the population in cities is growing exponentially and the land is limited, there is a need of vertical growth of buildings in these cities. So, for the fulfillment of this purpose a large number of medium to high rise buildings are coming up these days. But in

\footnotetext{
*Corresponding author: kuddus@ce.kuet.ac.bd

This is an open access article under the CC-BY license (https://creativecommons.org/licenses/by/4.0/).
} 
medium and high rise buildings, the conventional reinforced concrete construction cannot be adopted as there is increased dead load along with span restrictions, less stiffness and framework which is quite vulnerable to hazards. The objectives of this study to design a multi-storied car parking in this cyclone prone area include: to analyse and design G+19 storied R.C.C., Steel and Steel-Concrete composite buildings of same plan using ETABS 2013 software and to compare the structural parameters with the cost effectiveness of composite building over traditional reinforced concrete and steel structure.

In the construction industry in Bangladesh, use of steel is very less as compared to other developing nations like China, Brazil etc. Steel concrete composite frames use more steel and prove to be an economic approach to solving the problems faced in medium to high rise building structures. It has been found that use of composite members in construction is more effective and economic than using reinforced concrete members. Steel-concrete composite construction means steel section encased in concrete for columns \& the concrete slab or profiled deck slab is connected to the steel beam with the help of mechanical shear connectors so that they act as a single unit [2]. Reference [3] stated that apart from economy of material and speed of construction, composite structures, due to being lightweight, inflict less severe foundation conditions hence results in greater cost savings. Reference [4] evaluated the seismic performance of multi-storeyed building for which they have considered Steel-Concrete Composite and R.C.C. For their analysis the methods that they used were Equivalent static method and Linear Dynamic Response Spectrum Analysis. The results thus obtained were analysed and compared with each other. [5] Proposed a performance based fragility analysis based method in which the uncertainty due to variability in ground motion and structures are considered. By the proposed method of fragility analysis they performed analysis of a 15 storied building having composite beam and concrete filled square steel tube column. [6] Have discussed clauses and deficiencies of the Eurocode which earlier used to cause problem for the designers. For obtaining the response of the frames, methods of pushover analysis were also employed. Their main purpose was to study and investigate if the designed structure could behave in an elastically dissipative way. [7] Considered steel-concrete composite with RCC options for analysing a $\mathrm{B}+\mathrm{G}+15$ building which is situated in earthquake zone III and earthquake loading is as per the guidelines of IS1893(part-I): 2002. The parameters like bending moment and maximum shear force were coming more for RCC structure than the composite structure. Their work suggested that composite framed structures have many benefits over the traditional RC structures for high rise buildings. [8] Used a comparative method of study for RCC, Composite and steel options in a G+30 story commercial building situated in earthquake Zone IV. For this they used Equivalent static method and used the software ETABS. The comparative study included size, deflections, material consumption of members in RCC and steel sections as compared to Composite sections was also studied closely and based on this study cost comparison analysis was also performed.

\section{Structural Analysis}

In general, the Structural system of the building in a 3-D complex assemblage of various combination of inters connected structural elements. The primary function of the structural system is to carry effectively and safely of the loads acting on and to transmit them to the foundation. A structural system is therefore, expected to:

- Carry static and dynamic loads.

- Carry lateral loads due to wind and earthquake effects.

- Resist stress caused by temperature and shrinkage effects.

- Resist external or internal blast and impact loads.

- Resist and help damp vibrations and fatigue effects.

\subsection{Action of Loads}

Load acting on the structure generated either directly by man or forces of nature. There are two basic building loads- geophysical and manmade considered in this case. The geophysical forces, being the result of continuous change in nature, may further subdivided into gravitational, meteorological forces. As a result of gravity, the weight of the building itself produces the structure forces called dead toad and this load remains constant throughout the building life span. The man made sources of loading may be due to shocks generated by cars, elevators, machines and so on, or they may be due to the movement of people and equipment or the result of blast and impact. All the gravity vertical loads and horizontal loads are considered according to the guideline of Bangladesh National Building Code (BNBC 2010).

\subsubsection{Dead Load}

Dead load counted as the static forces caused by the weight of every element within the structure. The forces resulting in dead load bearing elements of building floor and ceiling finishes, permanent partition walls, facade cladding, storage tanks, mechanical distribution System and so on, the combined weight of all these elements makes up the dead load of a building. 
Dead load for this structural member has been assessed based on the forces due to:

- Weight of the member itself,

- Weight of all materials of construction incorporated into the building to be supported by the member.

- Weight of permanent partitions,

- Weight of fixed service equipment, and

- Net effect of pre-stressing.

\subsubsection{Live Load}

Live load is considered load superimposed by the use or occupancy of the building not including the environmental loads such as wind load, rain load, earthquake load or dead load.The live loads used for the structural design of floors, roof and the supporting members shall be the greatest applied loads arising from the intended use or occupancy of the building, or from the stacking of materials and the use of equipment and propping during construction, but shall not be less than the minimum design live loads set out by the provisions of BNBC 2010 code.

\subsubsection{Wind Load}

Wind is the term used for air in motion and is usually applied to the structure as horizontal motion of atmosphere. Wind action in building is dynamic and is influenced by such environmental factors as form of terrains, height, exposure category, structure type, building location, basic wind speed as well as arrangement of the building itself. In this study the wind load is considered according to the BNBC guideline for wind load calculation for Mongla, Bagerhat area, Bangladesh that is considered as $279 \mathrm{~km} / \mathrm{hr}$.

\subsubsection{Seismic Load}

Earthquake loading considered as of the building mass that result from the shaking of itself by a seismic disturbance. When earthquake occurs, there intensity is related inversely to their frequency of occurrence, severe earthquake is rare, moderate, once occurs more often and minor once occur more relatively frequent. The general philosophy of earthquake resistant design for buildings is based on the principles that they should-

- Resist minor earthquake without damage

- Resist moderate earthquake without structural damage but accepting the probability of nonstructural damage

- Resist average earthquake with the probability of structural as well as nonstructural damage without collapse

\subsubsection{Analysis Procedure}

Most building code suggests two ways of carrying analysis for buildings subjected to seismic loads i.e. the equivalent static force procedure and a dynamic analysis procedure based on "accepted principles of dynamics". The equivalent static force procedure has been used for many years now and its use is quite straightforward. However, true dynamic analysis procedures, particularly response spectrum analysis and time history analysis have gained foothold in the design offices recently to find out the actual behavior of structures imposed on lateral loads (Sam Kassegne, 1999). In this analysis, the equivalent static force procedure has been adopted; the magnitude of the force is based on an estimate of the fundamental period of the structure, as well as on other factors such as the seismicity of the area, operational importance factor, the energy absorption capacity of the structural system and the dead weight of the building. A response spectrum analysis has conducted by using mass and elastic stiffness of the seismic-force-resisting system to determine the natural modes of vibration for the structure including the period of each mode, the modal shape, the modal participation factor and mass. The analysis has included sufficient number of modes to obtain a combined modal mass participation of at least 90 percent of the actual mass in each of two orthogonal directions. However, for model designing main factors considered such as grid spacing, floor shape, floor height and column section were considered. Three separate G+19 storied R.C.C, steel as well as composite (steel-concrete) building of same plan were modeled by using ETABS 2013 software to compare their structural parameters and required estimated material cost.

\section{Architectural Details of Structure}

To study the behavior of high rise building under static and dynamic forces (Earthquake zone III and highly cyclone prone area) as per UBC 94 and BNBC 2010, where building is situated, a typical parking structure's plan is selected with area covering $42 \mathrm{~m} \times 32 \mathrm{~m}$ with $5 \mathrm{~m} \times 6 \mathrm{~m}$ grid. The building is designed as a car parking in the Mongla Sea Port of significant wind speed area, Bangladesh. The basic wind is considered $279 \mathrm{~km} / \mathrm{hr}$, according to the Bangladesh National Building Code (BNBC 2010). All dimensions are given in meter. The building is designed as 
a flat plate floor system with edge beam. Plan and column layout of the building has shown in the Figure 1 and 2, respectively.

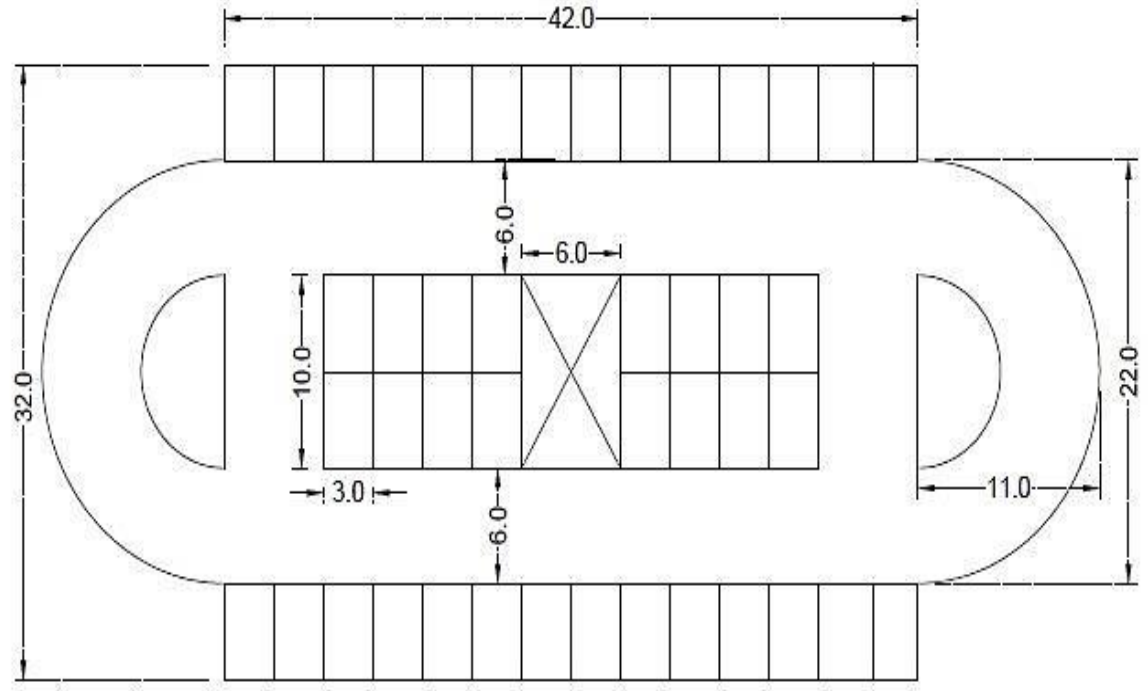

Figure 1. Typical plan of $\mathrm{G}+19$ storied car parking building

In ETABS, after providing the story heights and story no's for both the buildings, this $3 \mathrm{D}$ model was generated to carry out the analysis and design procedure. At the middle of A7-A8 shear walls were drawn as shown in the Figure 1, so that the building provides more stiffness against lateral loads. The experimental equipment included flume, tail gate, measuring carriage and devices for measuring the discharge and water surface level. On both the buildings, same loading values were applied for our comparison process. All the frames and slabs were assigned with Dead load, Live load, Stair live load, Wall load, Partition wall load with the following values listed in the table and the buildings were assigned with Wind and Earthquake loads as per UBC 94, ASCE 10-7 and BNBC 2010 code prohibition. Seismic zone co-efficient, exposure category, Response modification factor, wind speed, importance co-efficient were input to carry out the lateral load analysis.

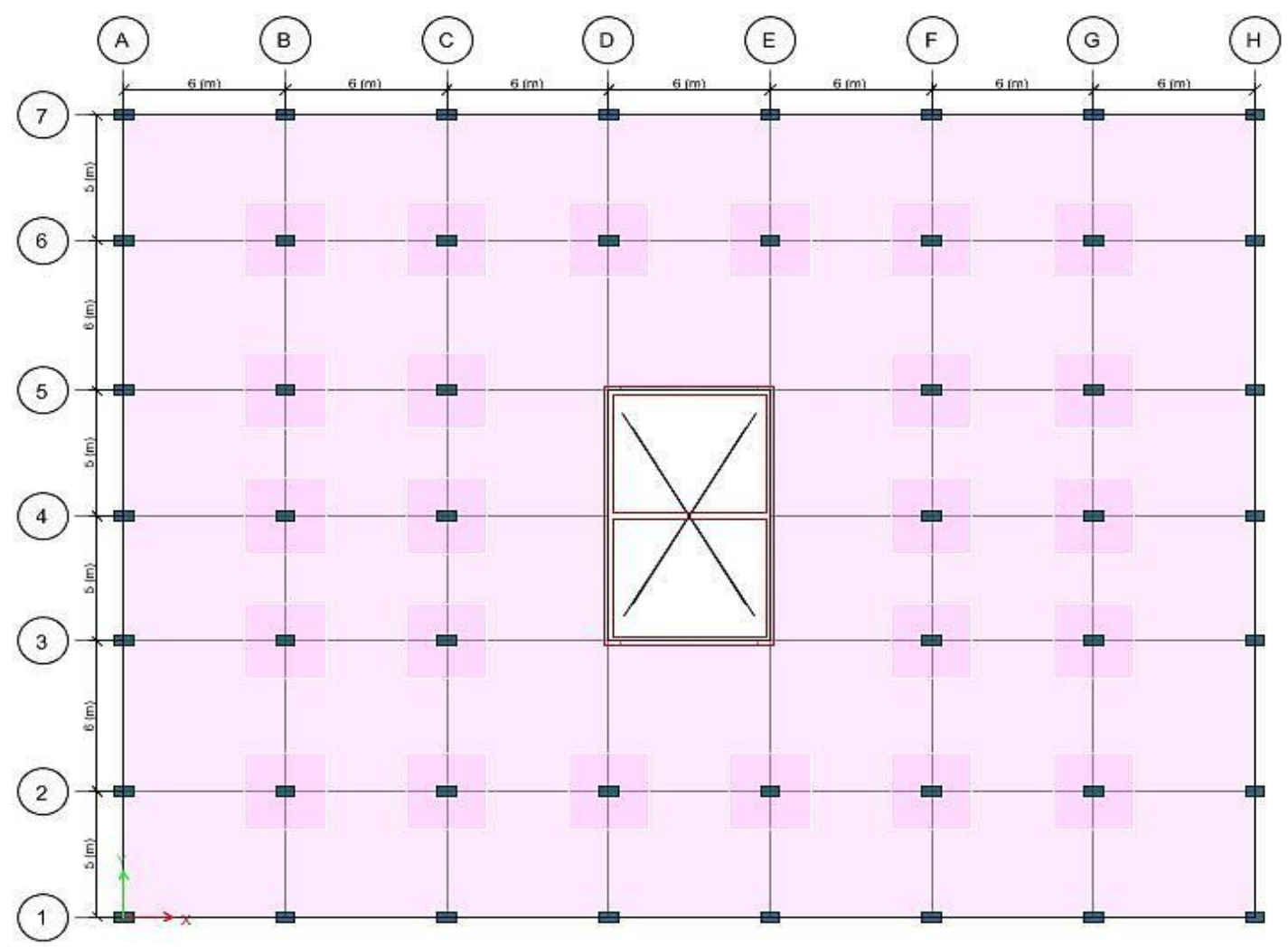

Figure 2. Typical beam-column layout the building 


\subsection{Modeling with ETABS}

3-D model has been prepared for the frame static and dynamic analysis of the building in ETABS version 13 as shown in the Figure 3. Following table provides the data and properties of the sections of the buildings. The details of analysis and design data are given in the Table 1 and 2.

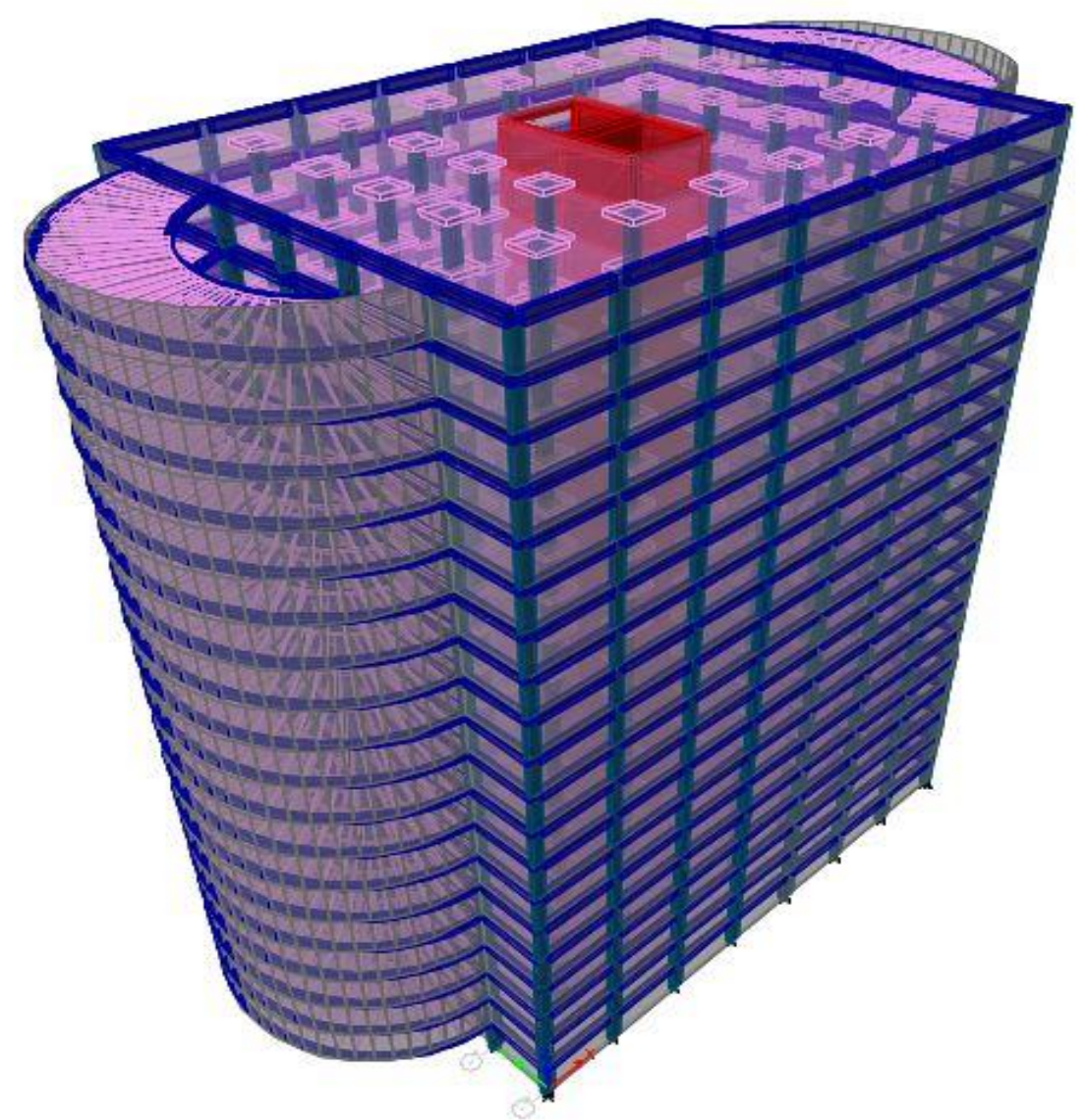

Figure 3. Elevation of building modelled with ETABS

There are many structural Engineering software in which Design, analyze, and collaboration are more accurate that support the Building Information Designing process. Basically all are almost the same but most commonly used cases for analyzing are RCC structures \& steel structures are ETABS. The advantage that ETABS offer over the SAP2000 is that it has more advanced computation algorithms which are implemented to analyze any complex high rise structure in lesser resources (time \& memory). Also ETABS has more user friendly input options to generate the complex high rise structure's model, whereas in SAP2000, Staad Pro, it's difficult to model discretely. ETABS is the most advanced structural Engineering software providing facility for:

- Auto calculation of beam reinforcements based on moments at column face, rather than at column centerline; and column reinforcements based on moments at beam soffit, rather than at beam centerline

- Construction sequence analysis

- Push-over analysis

- Shear wall design that's practically very useful

- Live load reduction for upper floors

- Earth quake force can be applied in any angle

- Modeling tapered concrete beams

- Floor load for irregular panels, that is easy to do

- Design of columns with cross section of any arbitrary shape

- The modal combination methods adopted by default and diaphragm action

- Automatic lumping of masses for earthquake and choice of Eigen or Ritz vector for response spectrum analysis 
Table 1. Details of data for analysis of RCC, STEEL and Composite structure

\begin{tabular}{|c|c|}
\hline Plan dimension & $42 m \times 32 m$ \\
\hline Total Height of building G+19 story & $60 \mathrm{~m}$ \\
\hline Car capacity & 2200 \\
\hline Height of each story & $3 \mathrm{~m}$ \\
\hline Height of parapet & $1 \mathrm{~m}$ \\
\hline Thickness of R.C.C slab & $250 \mathrm{~mm}$ \\
\hline Thickness of shear wall & $300 \mathrm{~mm}$ \\
\hline Live load parking area & $4 \mathrm{kN} / \mathrm{sq}-\mathrm{m}$ \\
\hline Floor finish load & $1.5 \mathrm{kN} / \mathrm{sq}-\mathrm{m}$ \\
\hline Wall thickness & $150 \mathrm{~mm}$ thick wall \\
\hline Stair case loading & $4 \mathrm{kN} / \mathrm{sq}-\mathrm{m}$ \\
\hline Seismic parameters & $\begin{array}{c}\text { Design code: UBC } 94 \\
\text { Zone: I } \\
\text { Soil type: Hard soil } \\
\text { Importance factor: } 1.25 \\
\text { Site coefficient: } 1.5 \\
\text { Response factor: } 8 \\
\text { Time period: Program Calculated } \\
\text { Seismic zone factor: } 0.075 \\
\text { Earthquake load in X and Y direction. } \\
\text { Rigid frame diaphragm }\end{array}$ \\
\hline Wind speed & $\begin{array}{l}\text { Design code: UBC-94 } \\
\text { Wind velocity: } 131 \mathrm{mph} \\
\text { Exposure type: B } \\
\text { Importance factor: } 1.25\end{array}$ \\
\hline concrete strength & $35 \mathrm{mpa}$ \\
\hline Rebar stress & 60 grade \\
\hline Damping ratio & $5 \%$ \\
\hline
\end{tabular}

Table 2. Loads considered for study and design code

\begin{tabular}{cccc}
\hline Models & Loads & Value & Design \\
\hline & Live & $4 \mathrm{kN} / \mathrm{Sq} \cdot \mathrm{m}$ & \\
RCC , STEEL and & Wall & $2 \mathrm{kN} / \mathrm{Sq} \cdot \mathrm{m}$ & ACI 318-08, Euro Code, AISC \\
Composite & Floor Finish & $1.5 \mathrm{kN} / \mathrm{Sq} \cdot \mathrm{m}$ & $360-10$ and BNBC code $[8,9]$ \\
& Stair Case live load & $4 \mathrm{kN} / \mathrm{Sq} \cdot \mathrm{m}$ & \\
\hline
\end{tabular}

As code represents that above $90 \%$ mass should be considered while running Response spectrum, so mode no 20 were selected for getting above $90 \%$ of total mass source of the buildings to affect for the seismic load pattern. The models were checked for the frame sections and material properties so that they were assigned as described. Table 3 and Table 4. represent story wise beam-column section data.

Table 3. Column section considered

\begin{tabular}{ccc}
\hline R.C.C & STEEL & COMPOSITE \\
\hline $0.4 m \times 0.7 \mathrm{~m}$ & & Composite column with concrete section \\
Floor level $6-20$ & Column section: & $0.3 \mathrm{~m} \times 0.45 \mathrm{~m}$ \\
$0.4 \mathrm{~m} \times 0.9 \mathrm{~m}$ & HE $400 \mathrm{M}$ & Steel section: HP $10 \times 57$ \\
Floor level $0-5$ & & \\
\hline
\end{tabular}


Table 4. Beam section considered

\begin{tabular}{ccc}
\hline R.C.C & STEEL & COMPOSITE \\
\hline & Main beam: IPE 400 & Main beam: W $16 \times 100$ \\
$\begin{array}{c}\text { External perimeter beam: } \\
0.4 \mathrm{~m} \times 0.8 \mathrm{~m}\end{array}$ & Secondary beam: IPE 270 & Secondary beam: W $10 \times 12$ \\
& Bracing : W $8 \times 40$ & \\
\hline
\end{tabular}

\section{Analysis Results and Cost Comparison}

For R.C.C., Steel and Composite model, analysis was performed to get the structural parameter magnitudes and directions and the comparison of them between the three buildings are tabulated. Those comparisons are showed in below. Displacement obtained from the both equivalent static analysis and response spectrum analysis is tabulated as below and individual graph are plotted to compare the parameter with each other. It is observed that story displacement in Equivalent Static Analysis in X-direction is less for Steel frame as compared to Composite and R.C.C frame. Composite frame has the highest values of story displacement. The differences in story displacement for different stories along X and Y direction are owing to orientation of column sections is shown in Figure 4. Moment of inertia of column sections are different in both directions. On the other hand displacement due to dynamic analysis is higher for steel frame and lower for R.C.C frame due to the difference in self-weight this result look like so.

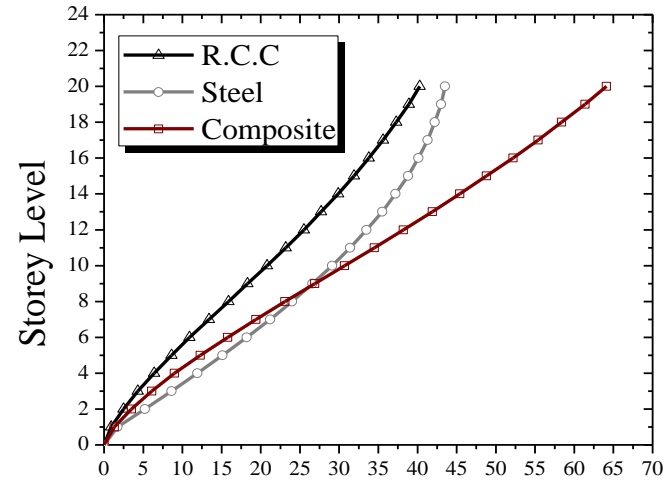

Displacment due to wind in $\mathrm{X}$ direction

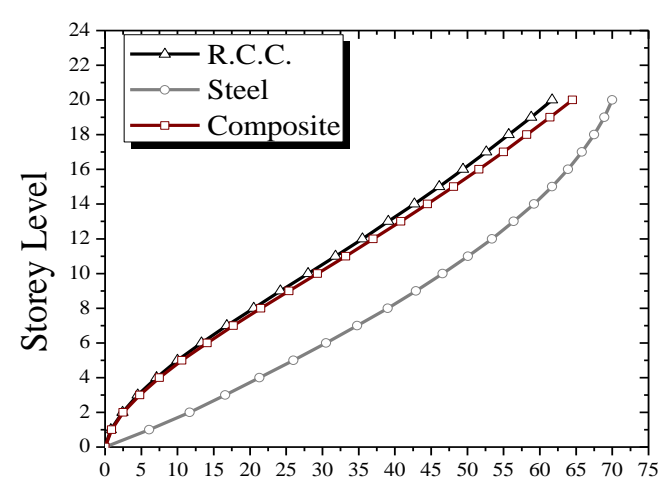

Displacement due to wind in Y direction

Figure 4. Comparison of story displacement in both directions for wind load

Base reaction and weight of the structure also plays an important rule. The value of base reaction, base shear in both directions and weight of the structure for different cases are given in the Table 5. It is obtained that Base Shear for RCC frame is maximum because the weight of the RCC frame is more than the steel and the composite frame. For the steel frame the value of base share is minimum for its lower self-weight. Here all design of the three structure is performed by using software ETABS 2013. Hence the amount of material is estimated using those data and the cost is calculated using the Bangladesh Public Works Department (PWD) rate schedule 2014. Figure 5. stress contour of a typical floor and Figure 6. shows the material cost for the three options of building. The material cost of the building frame only for super-structure (excluding labor, transportation \& fabrication cost) is estimated and shown in Table 6 , Table 7. and Table 8. 

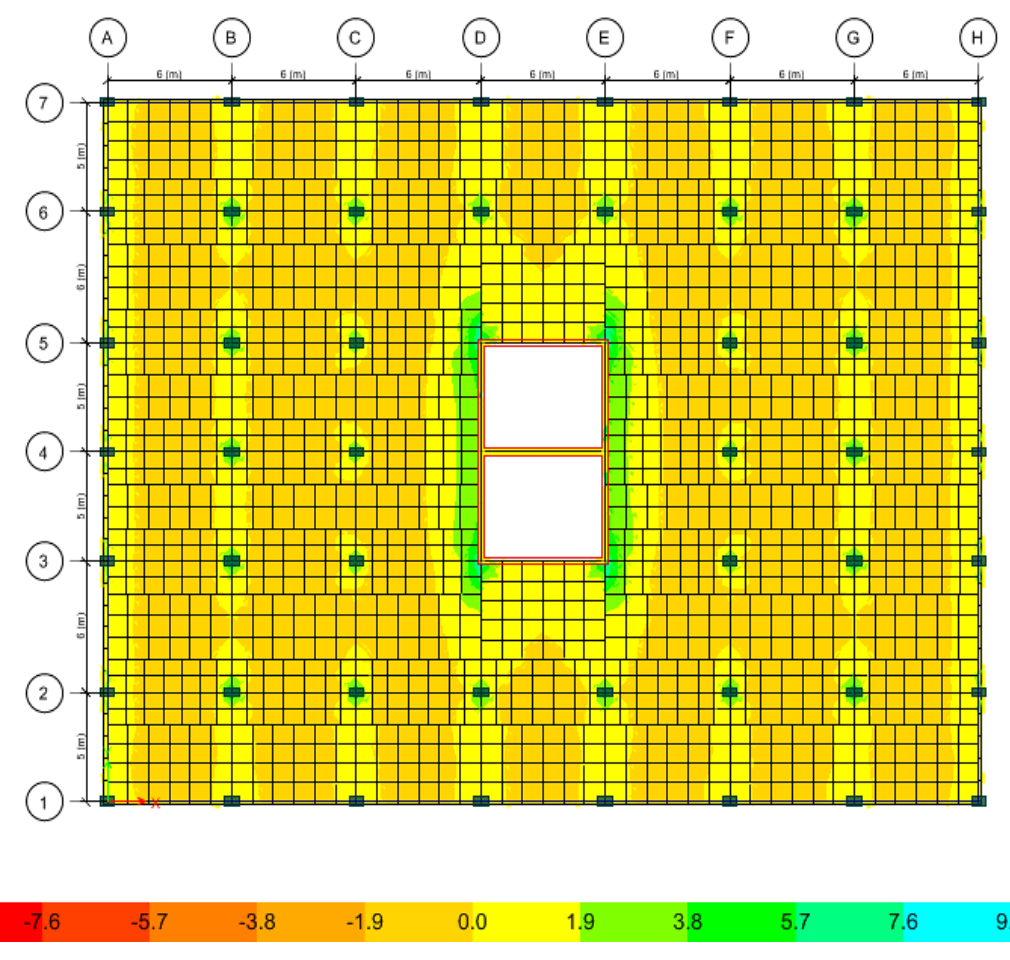

Figure 5. Stress concentration of a typical floor

Table 5. Base reaction, base shear and weight of the different options structure

\begin{tabular}{|c|c|c|c|c|}
\hline \multicolumn{2}{|c|}{ Force Type } & COMPOSITE & STEEL & R.C.C. \\
\hline \multicolumn{2}{|c|}{ Base Reaction (kN) } & 363229 & 372728 & 462300 \\
\hline \multicolumn{2}{|c|}{ Dead Weight $(\mathrm{kN})$} & 106518 & 110503 & 197901 \\
\hline \multirow{4}{*}{$\begin{array}{l}\text { Base Shear } \\
\quad(\mathrm{kN})\end{array}$} & EQX & 2727.71 & 2526.004 & 4035.22 \\
\hline & EQY & 2727.74 & 2526.004 & 4034.99 \\
\hline & RSPX & 2728.21 & 2527.45 & 4037.21 \\
\hline & RSPY & 2728.02 & 2527.01 & 4036.34 \\
\hline
\end{tabular}

Table 6. Amount of materials and cost comparison for R.C.C. frame

\begin{tabular}{cccc}
\hline Material & Quantity Used & Rate of material & Amount (BDT) \\
\hline Reinforcing bar (MT) & 3150 & 62250 & $196,087,500$ \\
Concrete (Cum) & 8510 & 4500 & $38,295,000$ \\
\hline TOTAL & & $234,382,500$ \\
\hline
\end{tabular}

Table 7. Amount of materials and cost comparison for steel frame

\begin{tabular}{cccc}
\hline Material & Quantity Used & Rate of material & Amount (BDT) \\
\hline Reinforcing bar (MT) & 2840 & 63000 & $178,920,000$ \\
Concrete (Cum) & 2680 & 4500 & $12,060,000$ \\
\hline TOTAL & & & $190,980,000$ \\
\hline
\end{tabular}


Table 8. Amount of materials and cost comparison for composite frame

\begin{tabular}{cccc}
\hline Material & Quantity Used & Rate of material & Amount (BDT) \\
\hline Reinforcing bar (MT) & 2645 & 63000 & $166,635,000$ \\
Concrete (Cum) & 3870 & 4500 & $12,915,000$ \\
\hline TOTAL & & & $179,550,000$ \\
\hline
\end{tabular}

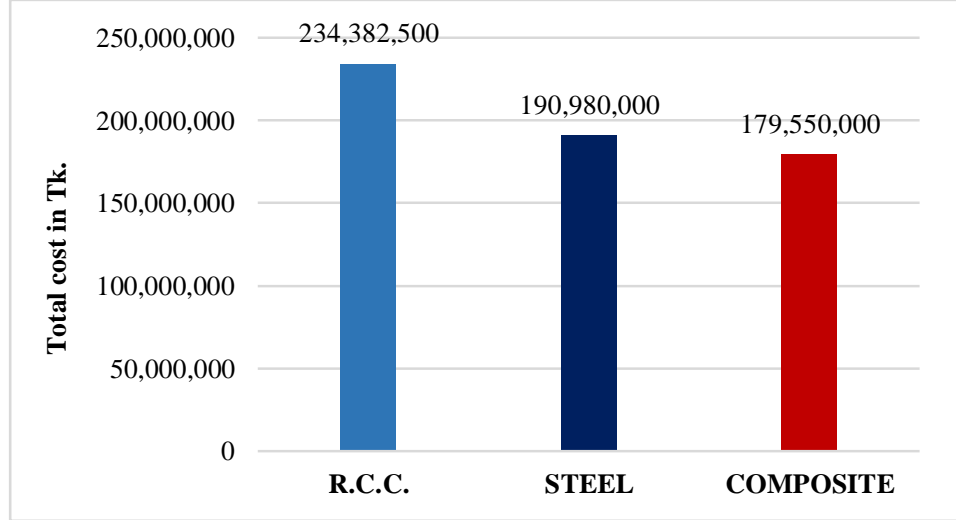

Figure 6. Comparison of total cost for different cases

Reduction Factor for Composite $=$ Cost of Composite/Cost of RCC

$$
\begin{aligned}
& =179,550,000 / 234,382,500 \\
& =0.77
\end{aligned}
$$

Reduction Factor for Steel $=$ Cost of Steel/Cost of RCC

$$
\begin{aligned}
& =190,980,000 / 234,382,500 \\
& =0.82
\end{aligned}
$$

Hence, reduction in cost of composite frame is $23 \%$ and steel frame is $18 \%$ compared with cost of RCC frame. This involves material cost only and doesn’t include fabrication cost, transportation cost, labor cost etc.

Again here a $42 \mathrm{~m} \times 32 \mathrm{~m}$ plan is considered then the total plan area $1344 \mathrm{~m}^{2}$. then the total cost per unit area can be calculated which is displayed

For R.C.C the total cost per unit length $=(234,382,500 /(50 \times 1344))$

$$
=8720 \mathrm{Tk} / \mathrm{m}^{2}
$$

For Steel the total cost per unit length $=(190,980,000 /(50 \times 1344))$

$$
=7105 \mathrm{Tk} / \mathrm{m}^{2}
$$

For composite the total cost per unit length $=(179,550,000 /(50 \times 1344))$

$$
=6680 \mathrm{Tk} / \mathrm{m}^{2}
$$

\section{Conclusion}

The outcomes are established after careful examination of results from the analysis and design of the structure. Steel-concrete composite frame system and its components are described to provide a brief introduction to composite construction. From the literature provided and considering the advantages of composite structure, it is clear that this type of construction can provide a satisfactory solution for the strength and serviceability requirements of commercial as well as residential buildings in Bangladesh. This paper also presents a feasibility study of composite structures in the current construction industry of Bangladesh. Based on the results, following conclusions are made:

- The results show the composite option is better than R.C.C. and steel as this option yield less material cost. 
- The storey displacement in X-direction is highest for composite frame which is increased by $12 \%$ and $45 \%$ for as compared to R.C.C. and steel frame. Due to using rigid RCC frame and cross bracing steel frame, the composite frame has the highest values of story displacement.

- The dead weight of composite structure is found to be $46 \%$ less than RCC structure which helps in reducing the foundation cost and for steel this reduction factor is $44 \%$.

- Base column reaction for RCC frame is maximum because the weight of the RCC frame is more than the steel and the composite frame. Base shear gets reduced by $21 \%$ for Composite frame and $19 \%$ for Steel frame in comparison to the RCC frame.

- Reduction in cost of composite frame is $25 \%$ and steel frame is $18 \%$ when compared to the cost of RCC frame. This involves material cost only and doesn't include fabrication cost, transportation cost, labor cost etc.

\section{References}

[1] BNBC, Bangladesh National Building Code, 2006, Dhaka, Bangladesh.

[2] Wagh S.A. \& Waghe U.P., “Comparative Study of R.C.C and Steel Concrete Composite Structures”, Journal of Engineering Research and Applications, ISSN: 2248-9622, Issue 4 (Version 1), (2010), pp.369-376, Vol. 4.

[3] Rackham, W., Couchman, G. H. Hicks, S. J. B., "Composite Slabs and Beams using steel decking: Best Practice for Design and Construction”, MCRMA, Technical Paper No. 13. SCI Publication P300 (Revised Edition), 2009.

[4] Charantimath S.S., Swapnil B.Cholekar, Birje Manjunath M., "Comparative Study on Structural Parameter of R.C.C and Composite Building”, Civil and Environmental Research, ISSN 2224-5790, ISSN 2225-0514 Vol.6, No.6, (2014).

[5] Jingbo LIU, Yangbing LIU, "Seismic behaviour analysis of steel-concrete Composite frame structure systems", Tsinghua University, Beijing, China, 2008.

[6] Johnson R.P, MICE MA., “Composite Structure of Steel and Concrete”, Blackwell, scientific publication, UK, Vol. 1, 1987.

[7] Koppad Shashikala, Itti S.V, "Comparative Study of R.C.C and Composite Multi-storeyed Buildings", International Journal of Engineering and Innovative Technology (IJEIT) Vol. 3, 2013.

[8] Panchal D.R., Marathe P.M., "Comparative Study of RCC, steel and composite (G+30 story) building”, Nirma University, Ahmedabad, India, 2011.

[9] AISC 360-10, Specification of structural steel building, An American national standard, American Institute Of Steel Construction, Inc., 2010. 